\title{
Changes of gonadotrophin surge inhibiting/attenuating factor activity in pig follicular fluid in relation to follicle size
}

\author{
M. Kita ${ }^{1}$, S. Taii ${ }^{1}$, N. Kataoka ${ }^{1}$, A. Shimatsu ${ }^{2}$, K. Nakao ${ }^{2}$ and T. Mori ${ }^{\mathrm{I}}$ \\ ${ }^{1}$ Department of Gynecology and Obstetrics, and ${ }^{2} 2$ nd Division Department of Internal Medicine, Faculty \\ of Medicine, Kyoto University, Sakyo-ku, Kyoto, 606, Japan
}

\begin{abstract}
The activity of GnSi/AF was measured in pig follicular fluid (pFF) from 58 individual follicles of various sizes, by bioassay using rat pituitary cells, to investigate the relationship between gonadotrophin surge inhibiting/attenuating factor (GnSI/AF) activity and follicular development. In addition, the correlation between GnSI/AF and inhibin activities and the content of sex steroids (oestradiol, progesterone and testosterone) of follicles was examined. The activity of GnSI/AF in pFF varied significantly $\left(0.155-1.69 \mathrm{U} \mathrm{\mu l}^{-1}\right)$ with size of the follicle. The activities (mean \pm SEM) were intermediate and constant in follicles with diameters from

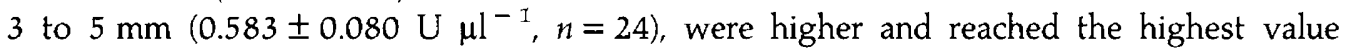

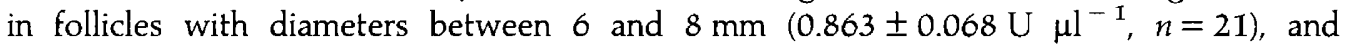
were lower, reaching the lowest value in follicles with diameters of 9 and $10 \mathrm{~mm}$

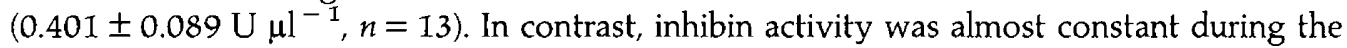
development of follicles, although individual values varied from 0.9 to $2.5 \mathrm{U}^{-1} \mathrm{I}^{-1}$. For follicles with diameters of $4-8 \mathrm{~mm}$, inhibin activity was $1.754 \pm 0.042 \mathrm{U}^{-1}(n=39)$;

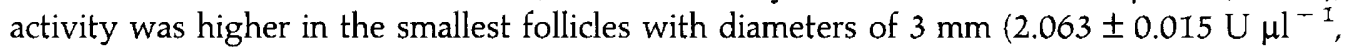
$n=6$ ) and was lower in follicles with diameter of $9 \mathrm{~mm}$, reaching the lowest value in follicles with diameter of $10 \mathrm{~mm}\left(1.176 \pm 0.068 \mathrm{U} \mathrm{\mu l}^{-1}, n=7\right)$; inhibin activity was not significantly correlated with $\mathrm{GnSI} / \mathrm{AF}$ activity. Steroid concentration increased in a similar pattern to that of GnSI/AF activity, but no marked decrease was noticed in the large follicles. These characteristic changes of the activity of GnSI/AF of follicles during development, especially in the preovulatory stage, suggest that GnSI/AF plays a role in the ovulatory process as an ovarian regulator for the timely occurrence of the LH surge.
\end{abstract}

\section{Introduction}

The mid-cycle LH surge is thought to be induced by the positive feedback action of oestrogen on the hypothalamicpituitary axis (Knobil and Hotchkiss, 1988). However, many workers reported the lack of an LH surge, in spite of high concentrations of serum oestradiol, particularly when stimulated by human menopausal gonadotrophin (hMG) or FSH administration (Schenken and Hodgen, 1983; Ferraretti et al., 1983; Littman and Hodgen, 1984). It has been shown that such phenomena during hMG or FSH administration may be achieved through the action of undefined ovarian non-steroidal factor(s), which reduce(s) the pituitary response to GnRH. This factor is called gonadotrophin surge-inhibiting factor (GnSIF) (Sopelak and Hodgen, 1984; Koppenaal et al., 1992), gonadotrophin surge-attenuating factor (GnSAF) (Messinis and Templeton, 1989; Knight et al., 1990), or gonadotrophin surge inhibiting/attenuating factor (GnSI/AF) (Culler, 1992). GnSI/AF was shown to be present in follicular fluid in pigs (Lagace et al., 1979; Danforth et al., 1987), monkeys (Schenken and Hodgen,

Received 5 July 1993
1983) and humans (Knight et al., 1990), and was demonstrated to be produced mainly in the ovaries of rats (de Koning $e t$ al., 1987) and monkeys (Littman and Hodgen, 1984). However, the physiological significance of this factor, as well as its structural identification, is still to be clarified.

In this study, the relationship between GnSI/AF activity and follicular development was investigated by evaluating the assay conditions for GnSI/AF bioactivity of fluid from follicles of various sizes and measuring their activity throughout follicular development. In addition, the activity of inhibin and concentrations of sex steroids were monitored.

\section{Materials and Methods}

\section{Isolation of $p F F$}

Pig ovaries were obtained from a local abattoir and transported to the laboratory in ice-cold $0.9 \%$ saline. Follicles were removed and classified according to their diameters. Fluid was collected from each follicle by aspiration with a needle. After centrifugation at $300 \boldsymbol{g}$ for 5 min the supernatant was stored at 
$-20^{\circ} \mathrm{C}$ until assay. Atretic follicles were excluded according to the macroscopic criteria of Moore (1978) and follicles containing oestradiol below the concentration of the mean - two SD of each class of diameter were also excluded. In all, 58 follicles were examined ( 6 to 11 follicles per size from 16 ovaries). In addition, for the reference preparation of $\mathrm{GnSI} / \mathrm{AF}$ and inhibin activities, a single batch of pig follicular fluid (pFF) was collected from follicles of various (mainly large) sizes.

\section{Pituitary cell culture}

Dispersed anterior pituitary cells were prepared according to the method of Vale et al. (1972), with minor modifications. Briefly, anterior pituitaries were removed from adult female Wistar rats $(240-270 \mathrm{~g})$, minced into small pieces, and dispersed in two steps. First, pituitary cells were incubated in Dulbecco's modified Eagle's medium (DMEM, Nissui Pharmaceutical Co. Ltd, Tokyo) containing $0.2 \%$ collagenase (Sigma Chemical Co., St Louis, MO), 0.2\% hyaluronidase (Sigma), 10\% fetal calf serum (FCS) (Gibco, Grand Island, NY), 100 U penicillin $\mathrm{ml}^{-1}$ and $100 \mu \mathrm{g}$ streptomycin $\mathrm{ml}^{-1}$ (Meiji Seika Kaisha Ltd, Tokyo) at $37^{\circ} \mathrm{C}$ for $30 \mathrm{~min}$, and were then incubated in $10 \mathrm{mmol} \mathrm{I}^{-1} \mathrm{Ca}^{2+}$ - and $\mathrm{Mg}^{2+}$-free PBS(-) containing $0.1 \%$ trypsin (Dojindo Laboratories, Kumamoto) and $0.001 \%$ DNAase I (Sigma) at $37^{\circ} \mathrm{C}$ for $10 \mathrm{~min}$ with gentle agitation. After dispersion, cells were washed and suspended in the medium (DMEM containing 10\% fetal calf serum and penicillin/streptomycin) at a concentration of $5 \times 10^{5}$ cells $\mathrm{ml}^{-1}$. The cell suspension was plated to each well $(250 \mu \mathrm{l}$ per well) of multi-well cell culture clusters (Costar, Cambridge, MA). Viability of dispersed cells was $>95 \%$ by trypan blue exclusion test.

\section{Charcoal treatment of $p F F$}

To remove steroids, $\mathrm{pFF}$ was treated before bioassay with dextran-coated charcoal (Norit A, Nacalai Tesque Inc., Tokyo, pretreated with $10 \%$ dextran (molecular weight 50000 70000 , Nacalai Tesque)). pFF was mixed with dextran-coated charcoal, rotated overnight at $4{ }^{\circ} \mathrm{C}$, and centrifuged at $3000 \mathrm{~g}$ for $30 \mathrm{~min}$. Supernatant was filtered through a $0.22 \mu \mathrm{m}$ filter and stored at $-20^{\circ} \mathrm{C}$.

\section{The reference preparation of GnSI/AF and inhibin activities}

The pooled pig follicular fluid (pFF) described above was treated with dextran-coated charcoal at $40 \mathrm{mg}$ charcoal $\mathrm{ml}^{-1}$ $\mathrm{pFF}$, and was referred to as the reference $\mathrm{pFF}$. By this treatment, oestradiol, progesterone and testosterone concentrations of this reference pFF were reduced below the sensitivities of the radioimmunoassays.

\section{Bioassay of GnSI/AF and inhibin activities}

GnSI/AF and inhibin bioactivities were measured according to the method of Danforth et al. (1987), except that each bioassay was performed separately because of the marked difference of the optimum assay range between them.

$\mathrm{GnSl} / \mathrm{AF}$ activity was measured as suppression of $\mathrm{GnRH}$ induced $\mathrm{LH}$ secretion. After plating for $48 \mathrm{~h}$, cells were washed twice with fresh medium and incubated in medium with samples (at a final concentration of $0.2 \%(\mathrm{v} / \mathrm{v})$, unless otherwise stated) for $48 \mathrm{~h}$. Cells were then washed twice with the fresh medium and incubated with samples in the presence or absence of $\mathrm{GnRH}\left(10 \mathrm{nmol} \mathrm{l}^{-1}\right)$ for $4 \mathrm{~h}$. The medium was collected and stored at $-20^{\circ} \mathrm{C}$ until assayed for $\mathrm{LH}$. The difference of $\mathrm{LH}$ secretion in the presence and absence of $\mathrm{GnRH}$ was referred to as GnRH-induced LH secretion. GnRH-induced secretion without samples throughout the incubation was referred to as the control.

Inhibin activity was determined by suppression of basal FSH secretion. After plating for $48 \mathrm{~h}$, cells were washed twice with fresh medium and incubated in the medium with or without (control) samples (at the final concentration of $0.02 \%, v / v, 10 \%$ of that for GnSI/AF bioassay, unless otherwise stated) for $48 \mathrm{~h}$; the medium was then collected and stored at $-20^{\circ} \mathrm{C}$ until assayed for FSH.

Both bioassays were carried out in triplicate for controls and samples.

\section{Radioimmunoassays of hormones}

Assays for rat $\mathrm{LH}$ and FSH were performed in duplicate using the $\mathrm{LH}$ and FSH radioimmunoassay kit generously provided by National Hormone and Pituitary Program, NIDDK. Rat-LH-RP-3 and Rat-FSH-RP-2 were used as the reference standard. The minimum detectable concentrations of LH and FSH were $10 \mathrm{pmol}^{-1}$ and $14 \mathrm{pmol}^{-1}$ and the intraand interassay coefficients of variance were $1.8 \%$ and $2.0 \%$ for LH and $5.8 \%$ and $12.8 \%$ for $\mathrm{FSH}$, respectively. Assays for oestradiol, progesterone and testosterone were performed in duplicate using commercial radioimmunoassay kits from Diagnostic Products Corporation (Los Angeles, CA). The intraassay coefficients of variation were less than $10 \%$. The sensitivities of the assays were $30 \mathrm{pmol} \mathrm{I}^{-1}, 160 \mathrm{pmoll}^{-1}$ and $140 \mathrm{pmol} \mathrm{I}^{-1}$, respectively.

\section{Statistical analysis}

Mean concentrations of gonadotrophin affected by reference pFF and steroids were analysed by Dunnet's multiple range test. Mean concentrations of $\mathrm{LH}$ affected by dextran-coated charcoal treated steroid rich $\mathrm{pFF}$, and $\mathrm{GnSI} / \mathrm{AF}$ and inhibin activities in individual pFF were analysed by Duncan's multiple range test. Correlation between $\mathrm{GnSI} / \mathrm{AF}$ and inhibin activities were analysed by Pearson's correlation coefficient. In all tests, $P<0.05$ was considered significant.

Calculation of the concentrations and $\mathrm{ED}_{50}$ values of $\mathrm{GnSI} / \mathrm{AF}$ and inhibin was performed by a linear regression analysis after a log-logit conversion.

\section{Results}

\section{Effects of steroids on bioassay}

The effect of steroids on the bioassay system was examined. Oestradiol, progesterone and testosterone at various concentrations ( $10 \mathrm{pmol} 1^{-1}-10 \mathrm{nmol} \mathrm{l}^{-1}$ ) were added singly into the incubation medium and gonadotrophin concentrations were measured (Fig. 1a). Although oestradiol and testosterone $\left(\leqq 100 \mathrm{pmol}^{-1}\right.$ ), and progesterone ( $\leqq 1 \mathrm{nmol} \mathrm{l}^{-1}$ ) had no significant effect on GnRH-induced LH secretion, Downloaded from Bioscientifica.com at 04/26/2023 11:19:45AM 
(a)

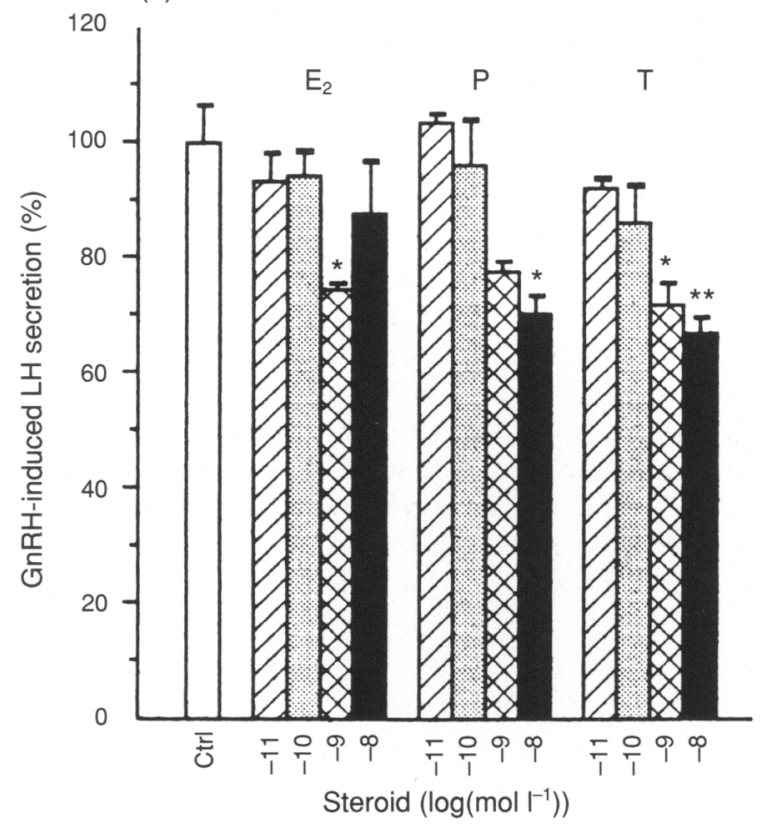

(b)

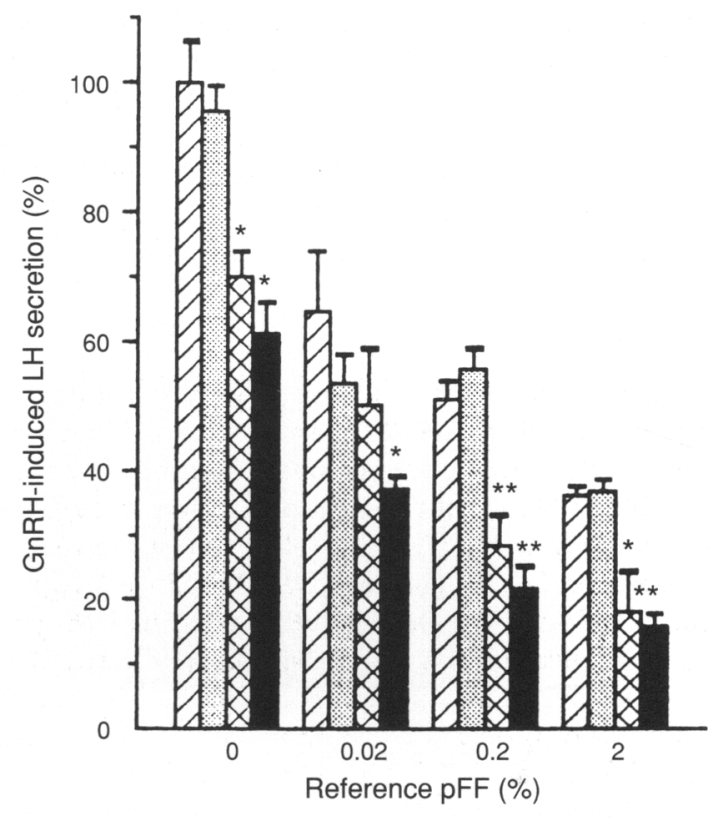

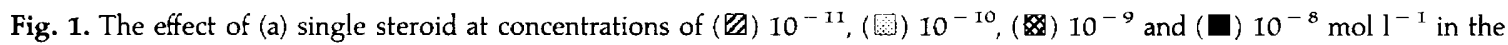
incubation medium without reference $\mathrm{pFF}$ and (b) combination of three steroids at the concentration of $(\mathbb{Z}) 10^{-11}$, (圈) $10^{-10}$, (10) $10^{-9}$ and (D) $10^{-8} \mathrm{~mol} \mathrm{l^{-1 }}$ with reference $\mathrm{pFF}$ of various concentrations on GnRH-induced LH secretion by rat cultured anterior pituitary cells. The control was the GnRH-induced LH secretion without pFF and steroids. GnRH-induced LH secretions are expressed as the percentage of the mean of the control (mean $+\operatorname{SEM}, n=3$ ). ${ }^{*}$ Significantly different from the control value (Dunnet's multiple range test, ${ }^{*} P<0.05,{ }^{* *} P<0.01$ ). Ctrl: control; $\mathrm{E}_{2}$ : oestradiol; $\mathrm{P}$ : progesterone; $\mathrm{T}$ : testosterone.

oestradiol at $I \mathrm{nmol} \mathrm{l}^{-1}$, progesterone at $\geqq 10 \mathrm{nmol} \mathrm{l}^{-1}$ and testosterone at $\geqq 1 \mathrm{nmol} \mathrm{l}^{-1}$ reduced it significantly $(P<0.05)$. Oestradiol, progesterone and testosterone in combination at the concentration of $100 \mathrm{pmol}^{-1}$ in the incubation medium with reference $\mathrm{pFF}$ at various concentrations $(0.02-2.0 \%)$ had no significant effect on GnRH-induced LH secretion, whereas $>1$ nmol $1^{-1}$ had a significant suppressive effect $(P<0.05)$ (Fig. Ib).

However, oestradiol, progesterone and testosterone at high concentrations ( $\geqq 10 \mathrm{nmol} \mathrm{l}^{-1}$ ) had stimulated basal FSH secretion, but these steroids added either singly or in combination at low concentration ( $10 \mathrm{pmol}^{-1}$, which was equivalent to that for GnSI/AF bioassay because sample concentration in incubation medium for inhibin bioassay was $10 \%$ of that for GnSI/AF bioassay) had no significant effect on basal FSH secretion (data not shown).

\section{Effect of treatment with dextran-coated charcoal on GnSI/AF activity and sex steroid concentration in $\mathrm{pFF}$}

The reference $\mathrm{pFF}$, which was essentially steroid free, was treated again with various concentrations of dextran-coated charcoal (0-1000 $\mathrm{mg}$ charcoal ml $\left.{ }^{-1} \mathrm{pFF}\right)$ and GnSI/AF activity was measured (Fig. 2). While treatment of the reference $\mathrm{pFF}$ with dextran-coated charcoal at concentrations $\leqq 100 \mathrm{mg}$ $\mathrm{ml}^{-1}$ did not reduce GnSI/AF activity significantly, dextran- coated charcoal treatment at $\geqq 400 \mathrm{mg} \mathrm{ml}^{-1}$ reduced it significantly $(P<0.05)$.

Steroid concentrations of fluid of large size follicles were measured by radioimmunoassay separately and FF containing high concentrations of steroids were chosen and mixed together to make a steroid-rich $\mathrm{pFF}$. This steroid-rich $\mathrm{pFF}$ was treated with various concentrations $\left(0-1000 \mathrm{mg} \mathrm{ml}^{-1}\right)$ of dextran-coated charcoal and GnSI/AF activity and oestradiol progesterone and testosterone concentrations were measured (Fig. 3). Although steroid concentrations of steroid-rich pFF were very high (oestradiol: $759 \mathrm{nmol} \mathrm{l^{-1 }}$, progesterone: $1.99 \mathrm{~mol} \mathrm{l}^{-1}$, testosterone: $805 \mathrm{nmol} \mathrm{l}^{-1}$ ), they were reduced drastically by dextran-coated charcoal treatment with increasing dextran-coated charcoal concentration. Treatment with dextran-coated charcoal at concentrations $\geqq 40 \mathrm{mg} \mathrm{ml}^{-1}$ reduced all steroid concentration of $\mathrm{pFF}$ to $<30 \mathrm{nmol} \mathrm{l}^{-1}$ This concentration of steroids was equivalent to $60 \mathrm{pmol}^{-1}$ in the assay medium because the sample was finally diluted to $0.2 \%$ when added into it, and was negligible for our bioassay as demonstrated above. The response curve of GnSl/AF activity to treatment with dextran-coated charcoal consisted of three segments, the first decrease of $\mathrm{GnSI} / \mathrm{AF}$ activity (1-10 $\mathrm{mg}$ dextran-coated charcoal $\mathrm{ml}^{-1}$ ), the stable segment (10-100 $\mathrm{mg} \mathrm{ml}^{-1}$ ) and the second decrease $\left(>100 \mathrm{mg} \mathrm{ml}^{-1}\right.$ ).

From these results, $40 \mathrm{mg} \mathrm{ml}^{-1}$ was chosen as the optimum concentration of dextran-coated charcoal that nullified the effect of steroids and preserved GnSl/AF activity in $\mathrm{pFF}$.

Downloaded from Bioscientifica.com at 04/26/2023 11:19:45AM 


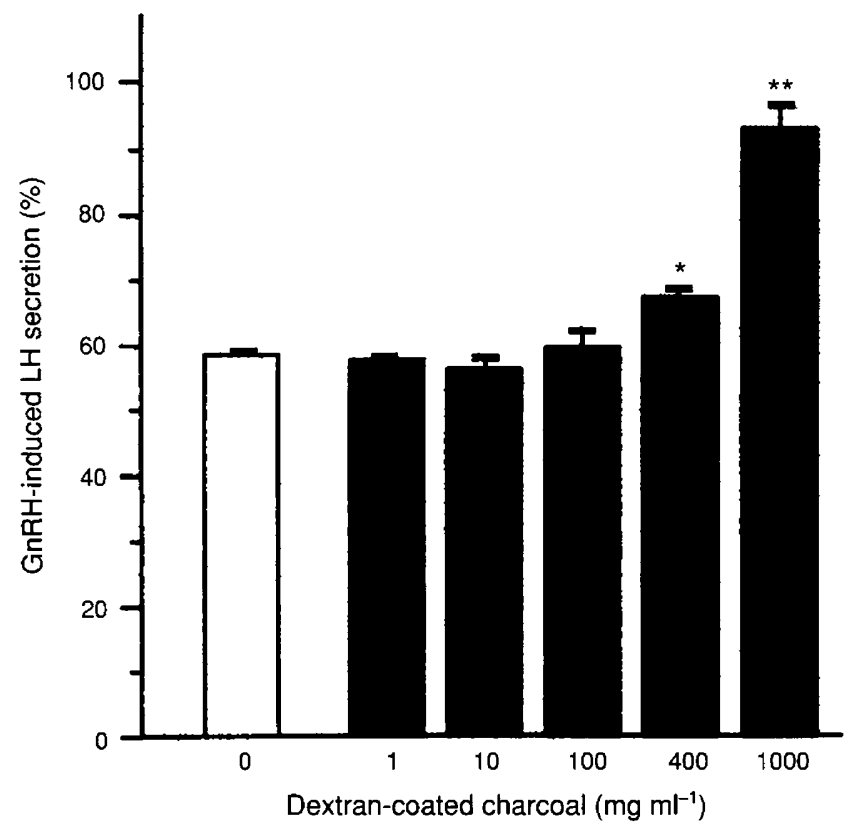

Fig. 2. The effect of treatment with dextran-coated charcoal on gonadotrophin surge inhibiting/attenuating factor (GnSI/AF) activity in the reference pig follicular fluid. Results are expressed as the percentage of the mean of the control (without pFF) (mean + SEM, $n=3$ ). Significantly different from untreated groups (Dunnet's multiple range test, $* P<0.05, * * P<0.01$ ).

Dose-response curve of reference $p F F$ on gonadotrophin secretion by cultured pituitary cells and calculation of GnSI/AF and inhibin activities

The reference pFF, which had been treated with the optimum concentration of dextran-coated charcoal at $40 \mathrm{mg} \mathrm{ml}^{-1}$, caused a dose-dependent inhibition of both basal FSH secretion and GnRH-induced LH secretion (Fig. 4). The control study using $2 \%$ of heat-treated (at $56^{\circ} \mathrm{C}$ for $30 \mathrm{~min}$ ) dextran coated charcoal treated pig serum indicates that protein loading alone was not a contributory factor. This dose-response curve of the reference $\mathrm{pFF}$ was referred to as the standard curve for $\mathrm{GnSI} / \mathrm{AF}$ and inhibin bioassay. After a log-logit conversion, the linear segments of the curve (five points between 0.02 and $2.0 \%$ for $\mathrm{GnSI} / \mathrm{AF}$, and between 0.005 and $0.02 \%$ for inhibin) were analysed for a linear regression. Results of both bioassays are shown (Table 1): $0.2 \%$ of the reference pFF in incubation medium caused approximately $50 \%$ suppression of $\mathrm{GnRH}-$ induced LH secretion (median effective dose; $\mathrm{ED}_{50}$ ), and $0.01 \%$ of reference $\mathrm{pFF}$ also caused approximately $50 \%$ suppression of basal FSH secretion ( $E D_{50}$ of inhibin activity). Because of the difference of $\mathrm{ED}_{50}$ values, GnSI/AF and inhibin activities of individual $\mathrm{pFF}$ were assayed separately. One microlitre of the reference $\mathrm{pFF}$ was defined to contain $\mathrm{I}$ unit of $\mathrm{GnSI} / \mathrm{AF}$ activity because $0.2 \%$ reference pFF in incubation medium caused $50 \%$ suppression of GnRH-induced LH secretion (Danforth et al, 1987). One microlitre of the reference $\mathrm{pFF}$ was also defined to contain 1 unit of inhibin activity for the convenience of expression. Both relative potencies of individual samples were calculated on the basis of this definition. (a)

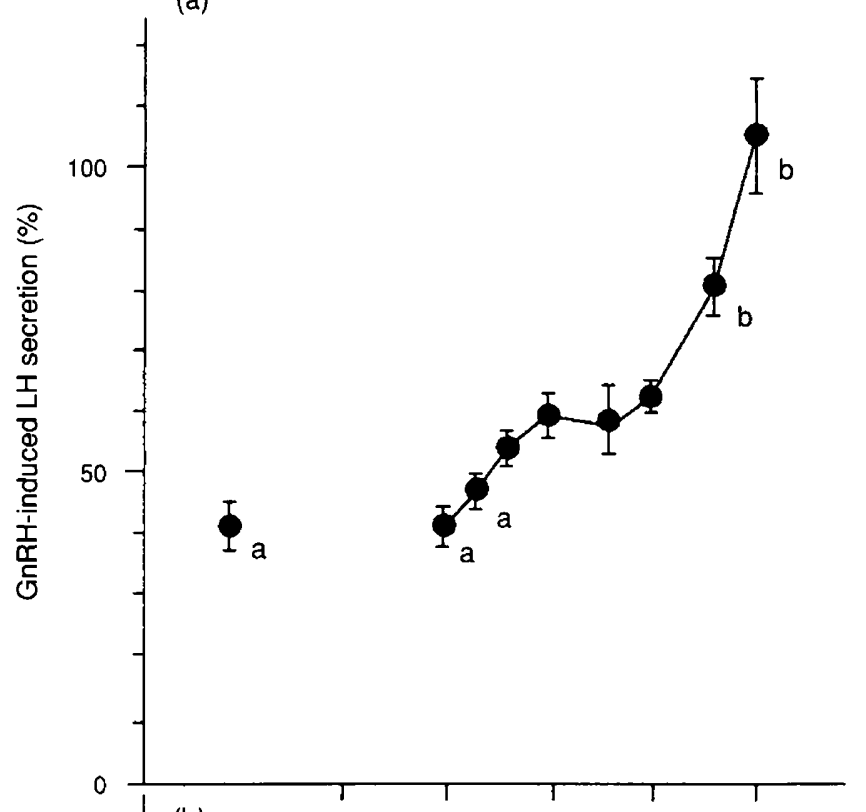

(b)

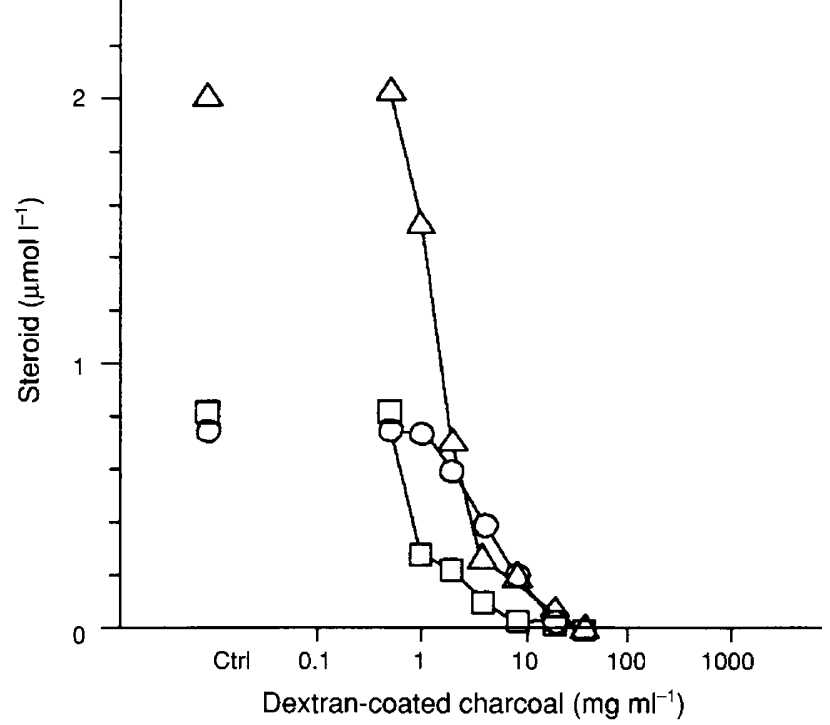

Fig. 3. The effect of treatment with dextran-coated charcoal on (a) gonadotrophin surge inhibiting/attenuating factor (GnSI/AF) activity and (b) steroid concentration in steroid-rich pig follicular fluid. Results are expressed as the percentage of the mean of the control (without $\mathrm{pFF}$ ) (mean $\pm \mathrm{SEM}, n=3$ ) for (O) GnSI/AF or as the mean concentrations of $(O)$ oestradiol, $(\triangle)$ progesterone and $(\square)$ testosterone measured by radioimmunoassay in duplicate. For $\mathrm{GnSl} / \mathrm{AF}$ activity, values with different letters are significantly different from one another (Duncan's multiple range test, $P<0.05$ ).

\section{GnSI/AF and inhibin activities and steroid concentration in individual $p F F$ in relation to follicular diameters}

GnSI/AF activity of individual pFF varied significantly according to follicular diameters and fluctuated between 0.155 and $1.69 \mathrm{U} \mathrm{Hl}^{-1}$. The activity (mean \pm SEM) was moderate and almost constant in the follicles with diameters from 3 to $5 \mathrm{~mm}$ $\left(0.583 \pm 0.080 \mathrm{U}^{-1} \mathrm{l}^{-1}, n=24\right)$, increased to the highest value Downloaded from Bioscientifica.com at 04/26/2023 11:19:45AM 

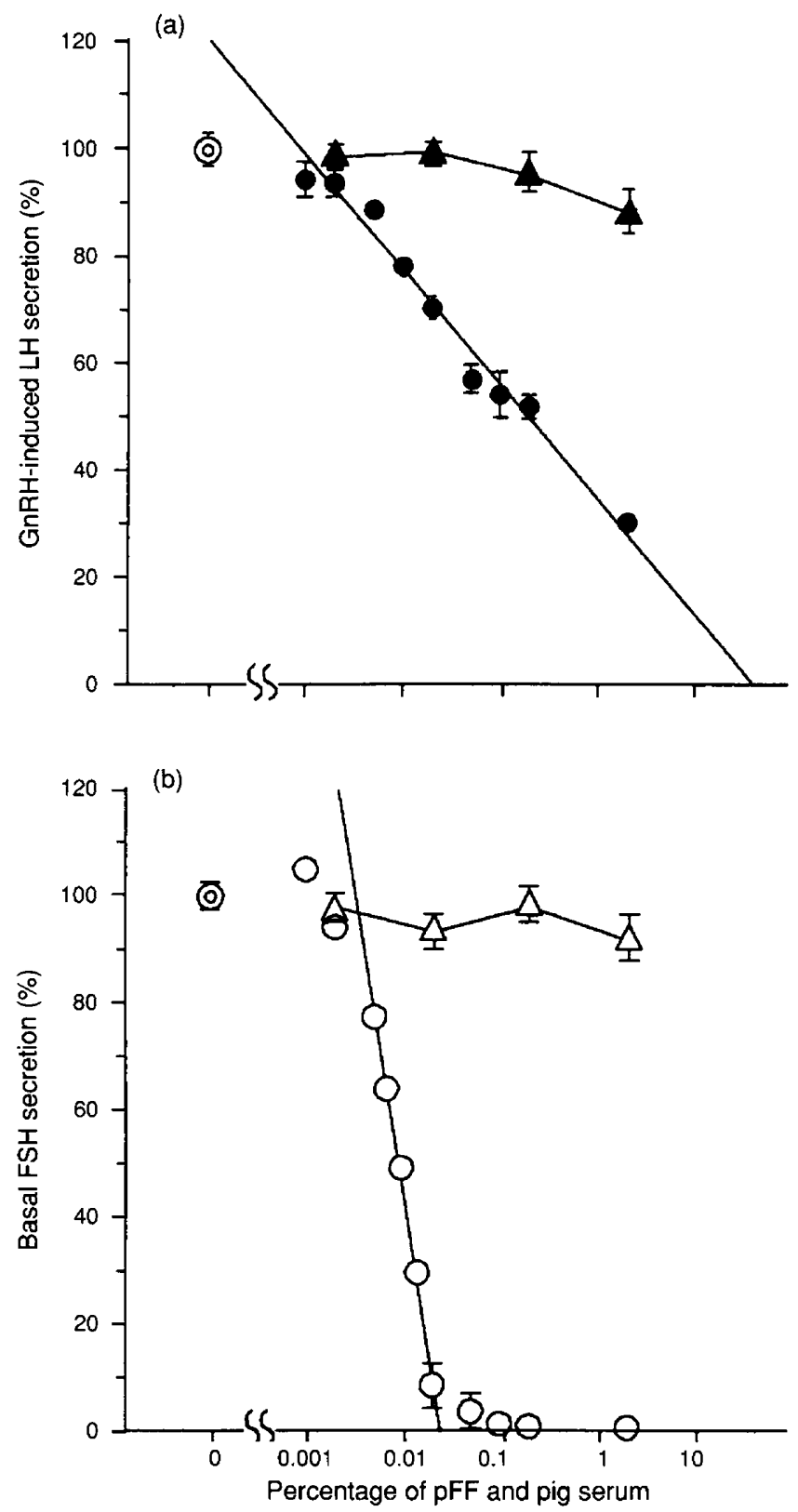

Fig. 4. The effect of $(O)$ the reference $\mathrm{pFF}$ and the heat-treated and $(\boldsymbol{\Delta})$ dextran-coated charcoal treated porcine serum on $\mathrm{GnRH}$-induced $\mathrm{LH}$ secretion and (b) the effect of the $(O) \mathrm{pFF}$ and $(\triangle)$ pig serum on basal FSH secretion by cultured rat anterior pituitary cells. ( $\bigcirc)$ represents the control value of gonadotrophin secretion without $\mathrm{pFF}$ or pig serum. Concentrations of pFF and pig serum are expressed as the percentage in the incubation medium. Gonadotrophin secretions are expressed as the percentage of the mean of the control (without $\mathrm{pFF}$ ) (mean $\pm \mathrm{SEM}, n=3$ ). Basal FSH secretion (control value, mean $\pm \mathrm{SEM}, n=3$ ) was $657 \pm 13.6 \mathrm{pmol} \mathrm{l}^{-1}$ in $48 \mathrm{~h}$, and LH secretion with or without $\mathrm{GnRH}\left(10 \mathrm{nmol} \mathrm{l}^{-1}\right.$ ) (mean $\pm \mathrm{SEM}, n=3$ ) was $1472 \pm 28.3 \mathrm{pmol} \mathrm{l}^{-\mathrm{I}}$ in $4 \mathrm{~h}$ and $44.8 \pm 1.72 \mathrm{pmol}^{-1}$ in $4 \mathrm{~h}$, respectively.

in the large follicles with diameters from 6 to $8 \mathrm{~mm}$ $\left(0.863 \pm 0.068 \mathrm{U}_{\mu \mathrm{I}^{-1}}, n=21\right)$ with the peak at $7 \mathrm{~mm}$

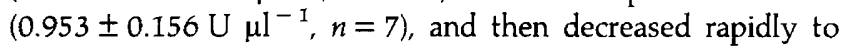
the lowest value in the large follicles with diameters of 9 and (a)

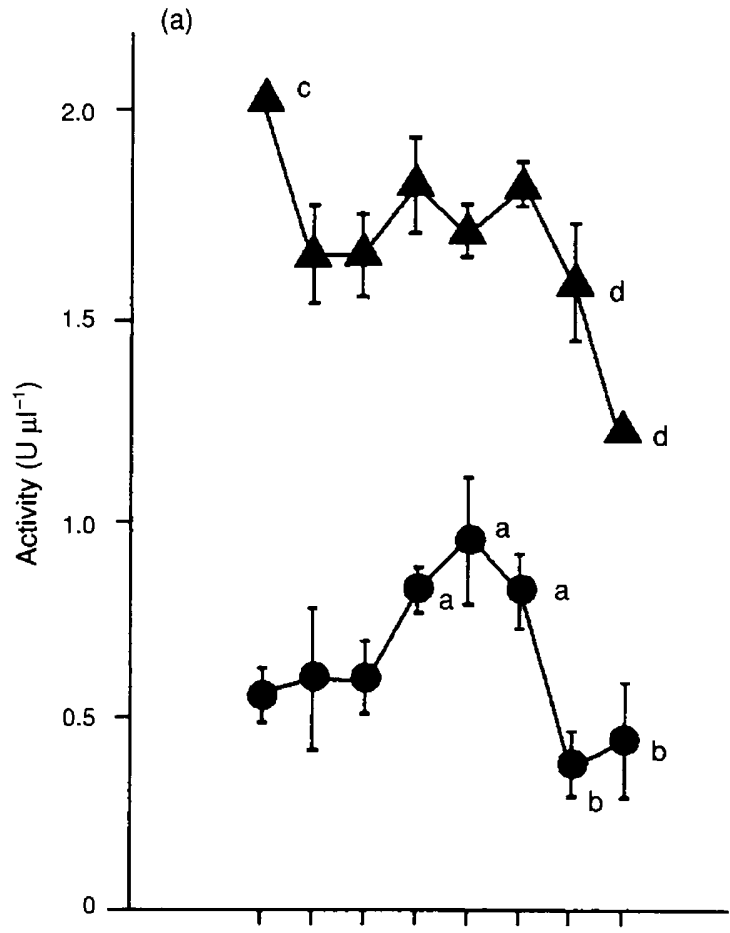

(b)

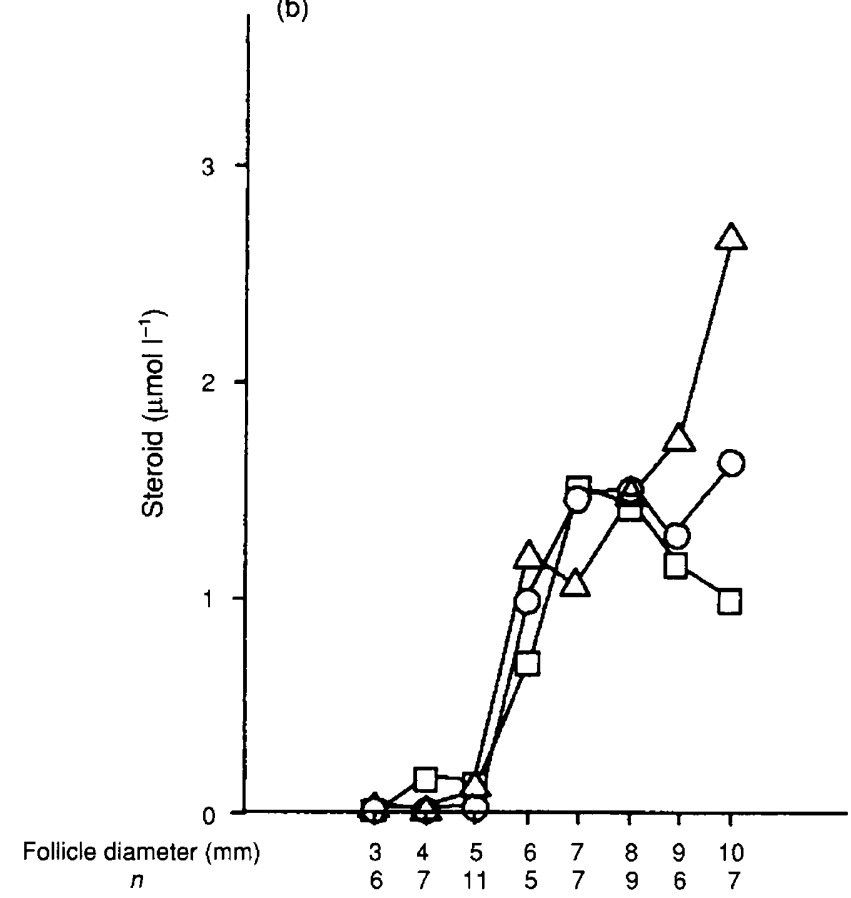

Fig. 5. Changes of (a) gonadotrophin surge inhibiting/attenuating factor (GnSI/AF) (O) and ( $\boldsymbol{\Delta})$ inhibin activities, and (b) steroid concentrations of $(O)$ oestradiol, $(\triangle)$ progesterone and $(\square)$ testosterone in individual pig follicles according to their diameters. The individual $\mathrm{pFF}$ from follicles classified every $1 \mathrm{~mm}$ was assayed for $\mathrm{GnSI} / \mathrm{AF}$ and inhibin activities and steroids. Results are expressed as the mean \pm SEM of GnSI/AF and inhibin activities and the mean concentrations of steroids. The number of follicles assayed is shown under each diameter. Values with different letters of GnSI/AF and inhibin activities are significantly different from one another (Duncan's multiple range test, $P<0.05$ ). 
Table 1. Bioassay statistics of gonadotrophin surge inhibiting/attenuating factor (GnSI/AF) and inhibin activities of pig follicular fluid

\begin{tabular}{|c|c|c|}
\hline & $\mathrm{GnSI} / \mathrm{AF}$ & Inhibin \\
\hline \multicolumn{3}{|l|}{ Standard curve } \\
\hline Analysed range $\left(U \mu^{-1}\right)$ & $0.1<x<10$ & $0.5<x<2$ \\
\hline Numbers of points analysed & 5 & 5 \\
\hline $\begin{array}{l}\text { Regression line } \\
\quad x ; \cup \mu l^{-1} \\
\quad y ; \% \text { of control }\end{array}$ & $\ln x=-0.11 y+6.35$ & $\ln x=-0.02 y+0.91$ \\
\hline$r^{2}$ & 0.99 & 0.99 \\
\hline$\lambda$ & $-0.0197 \sim-0.00102$ & $-0.004 \sim-0.000094$ \\
\hline Cultures dose $e^{-1}$ & 3 & 3 \\
\hline \multicolumn{3}{|l|}{ Samples } \\
\hline Cultures per sample & 3 & 3 \\
\hline Mean intra-assay CV (\%) & 16.7 & 7.6 \\
\hline
\end{tabular}

$r^{2}$ : coefficient of determination; $\lambda$ : index of precision (residual variance/slope); $\mathrm{CV}$ : coefficient of variation.

$10 \mathrm{~mm}\left(0.401 \pm 0.089 \mathrm{U}_{\mu}^{-1}, n=13\right)$. Although inhibin activity of individual $\mathrm{pFF}$ also varied from 0.9 to $2.5 \mathrm{U} \mathrm{\mu l}^{-1}$, its mean value was almost constant without a peak value during

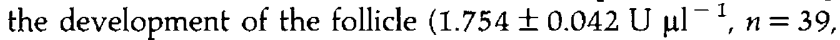
diameters from 4 to $8 \mathrm{~mm}$ ), except for high values in the smallest follicles with diameters of $3 \mathrm{~mm}(2.063 \pm 0.015 \mathrm{U}$ $\left.\mu \mathrm{l}^{-1}, n=6\right)$ and gradual decrease from diameters of $9 \mathrm{~mm}$ to the lowest value at diameters of $10 \mathrm{~mm}\left(1.176 \pm 0.068 \mathrm{U}_{\mu \mathrm{l}^{-1}}\right.$, $n=7)$.

There was no significant relationship between GnSI/AF and inhibin activities of individual follicles $(y=1.471+$ $0.3478 \times$ Pearson's correlation index; $r=0.3821$ ).

Large increases in steroid concentrations were noticed at follicular diameters from 5 to $6 \mathrm{~mm}$. Oestradiol and testosterone concentrations increased further and reached maximum values at follicle diameters of 7-8 $\mathrm{mm}$. Progesterone concentration increased continuously until a diameter of $10 \mathrm{~mm}$ was reached.

\section{Discussion}

GnSIF was thought to be the factor that blocks oestrogeninduced gonadotrophin surges in superovulated monkeys (Sopelak and Hodgen, 1984) and GnSAF was also described as a similar factor in women (Messinis and Templeton, 1989). Some other groups have also studied similar factors (Knight et al., 1990; Koppenaal et al., 1992). However, its identification or definite physiological roles are still to be clarified. In the present study, to elucidate the relationship between $\mathrm{GnSI} / \mathrm{AF}$ activity and follicular development, we examined the appropriate assay condition for the quantification of GnSI/AF activity in follicles of various sizes.

As sex steroids are well known to have direct effects on gonadotrophin secretion by cultured pituitary cells (Schally et al., 1973; Tang and Spies, 1975), treatment with dextran-coated charcoal has generally been used to remove steroids from samples, for example FF or serum (Schenken et al., 1984; Knight et al., 1990; Fowler et al., 1990a) to demonstrate the nonsteroidal GnSI/AF. But insufficient dextran-coated charcoal treatment of pFF may result in residual steroid which will have significant effects on the bioassay, and high concentrations could cause significant loss of GnSI/AF activity, like that of inhibin (Tsonis et al., 1983). Careful determination of the optimum condition of treatment is therefore critical, especially in measuring GnSI/AF activity in samples with a wide range of steroid concentration, as in the present study. As reported previously, high concentrations of steroids had significant effects on the bioassay system for GnSI/AF. The detection limit for steroids, added separately or in combination, to our bioassay system for $\mathrm{GnSI} / \mathrm{AF}$ was $100 \mathrm{pmol} \mathrm{l}^{-1}$. Steroids at this concentration were also undetected in our bioassay system for inhibin (because the final concentration of $\mathrm{pFF}$ in assay medium for inhibin bioassay was $10 \%$ of that for $\mathrm{GnSI} / \mathrm{AF}$ ). As expected, high concentrations of dextran-coated charcoal $\left(\geqq 400 \mathrm{mg} \mathrm{ml}^{-1}\right.$, charcoal/pFF) of $\mathrm{pFF}$ caused significant loss of GnSI/AF activity, and the maximum concentration to preserve $\mathrm{GnSI} / \mathrm{AF}$ activity was $100 \mathrm{mg} \mathrm{ml}^{-1}$. The minimum concentration of dextran-coated charcoal that could reduce steroid concentration of pFF to undetectable concentrations was $40 \mathrm{mg} \mathrm{ml}^{-1}$ and treatment at the conventional concentration (about $5 \mathrm{mg} \mathrm{ml}^{-1}$ ) was shown to be insufficient for steroid rich pFF from large follicles. The response curve of GnSI/AF activity to treatment with dextran-coated charcoal consisted of three segments. From the result, the first decrease of GnSI/AF activity was probably due to a reduction of steroids, and the second decrease was probably due to reduction of GnSI/AF activity by treatment with high concentration of dextran-coated charcoal. The concentration of dextrancoated charcoal for GnSI/AF bioassay was $40 \mathrm{mg} \mathrm{ml}^{-1}$, where the effect of steroids was removed and GnSI/AF activity was preserved.

In summary, (1) there was an increase of GnSI/AF activity accompanied by an increase of steroid concentration in follicles with diameters from 5 to $8 \mathrm{~mm}$; (2) a subsequent rapid decrease of $\mathrm{GnSI} / \mathrm{AF}$ activity in follicles of $9-10 \mathrm{~mm}$ without the decrease of steroid concentration and (3) there was a difference in the changing patterns of $\mathrm{GnSI} / \mathrm{AF}$ and inhibin activities in relation to follicular size.

Downloaded from Bioscientifica.com at 04/26/2023 11:19:45AM 
There have been few reports about the change of GnSI/AF activity of $\mathrm{FF}$ in relation to follicular stage. In rats, this activity in ovarian extracts did not change during the oestrous cycle, while inhibin-like activity was highest in dioestrus 2 and pro-oestrus (de Koning et al., 1989). Others reported that GnSI/AF was preferentially produced by small follicles in superovulated women and monkeys (Fowler et al., 1990b; Schenken et al., 1984). But it is difficult to compare our results with those of others because of considerable differences in methods used.

It has been suggested that $\mathrm{GnSI} / \mathrm{AF}$ is the regulator of the LH surge (Whitehead, 1990; Messinis and Templeton, 1991). The dynamic change of GnSl/AF activity of $\mathrm{pFF}$ during follicular development, especially during the preovulatory period as shown here, is appropriate to explain this hypothesis. If the plasma change of $\mathrm{GnSI} / \mathrm{AF}$ activity during follicular phase reflects that of FF reported here, the following could be speculated. The steroid concentrations increase according to the follicular development, and oestradiol at the high concentration increases the response of the anterior pituitary to $\mathrm{GnRH}$ and induces this positive feedback. The GnSI/AF activity also increases during follicular maturation, maintains the pituitary in a state of low responsiveness to $\mathrm{GnRH}$ to prevent the premature LH surge, and increases the gonadotrophin pool of the pituitary. The rapid decrease of $\mathrm{GnSl} / \mathrm{AF}$ activity just before ovulation at high concentrations of steroids can result in a maximum response of the pituitary. If the GnSI/AF activity decrease occurs before the initiation of the $\mathrm{LH}$ surge, the $\mathrm{LH}$ surge is triggered. If the decrease occurs during the LH surge, it promotes or enhances the LH surge to achieve sufficient amplitude and duration for adequate ovulation. However, it has been demonstrated that repeated exogenous $\mathrm{GnRH}$ injection provoke a large release of $\mathrm{LH}$, possibly without a change of GnSI/AF activity (Koppenaal et al., 1991). It is very difficult to compare this result with those reported here because of marked differences in experimental conditions. Further investigation will be necessary including detection of the plasma change of $\mathrm{GnSI} / \mathrm{AF}$ activity throughout the menstrual cycle.

A difference was shown between the changing pattern of $\mathrm{GnSI} / \mathrm{AF}$ and inhibin activities according to the size of the follicle. Inhibin activity in pFF was reported to decrease when measured by bioassay (Anderson and Hoover, 1982), and increase when measured by radioimmunoassay (Guthrie et al., 1992) during follicular maturation. The results reported here are similar to previous reports but inhibin activity measured in the study reported here may be underestimated because the treatment with dextran-coated charcoal was designed for GnSI/AF bioassay and it may be excessive for inhibin bioassay (Tsonis et al., 1983). However, as the effect of steroids on the inhibin bioassay was nullified by our treatment with dextrancoated charcoal, it appears that the overall changing pattern of inhibin activity in relation to follicular size reflects real changes.

The difference between GnSI/AF and inhibin is a matter of controversy. It has been reported that purified inhibin inhibits GnRH-induced LH secretion (Fukuda et al., 1986) and passive immunoneutralization using anti-inhibin $\alpha$-subunit serum recovers the preovulatory surge of an FSH-treated rat (Culler, 1992). The contribution of inhibin to GnSI/AF activity of pFF must therefore be considered. However, passive immunoneutralization against inhibin altered the GnRH-induced FSH secretion, but not that of LH secretion (River et al., 1990). Studies in vitro have also provided some evidence that GnSI/AF is different from inhibin (Danforth et al., 1987; Busbridge et al., 1990; Fowler et al., 1990a; Knight et al., 1990), and it has been demonstrated that the suppressive effect of GnRH-induced LH secretion of inhibin in $\mathrm{pFF}$ is negligible compared with that of GnSI/AF (Danforth et al., 1987). Although the present study was not designed for the elucidation of the difference between $\mathrm{GnSI} / \mathrm{AF}$ and inhibin, the discrepancy of the changing patterns of GnSI/AF (suppressive effect on GnRH-induced LH secretion) and inhibin (suppressive effect on basal FSH secretion) bioactivities demonstrated in the study reported here suggests the contribution of factors, including GnSI/AF, other than inhibin. We also obtained a crude GnSI/AF fraction with higher GnSI/AF activity and lower inhibin activity in our preliminary preparation from $\mathrm{pFF}$ (unpublished data). The final resolution on this matter awaits a structural identification of GnSI/AF.

In conclusion, we have shown the characteristic change of GnSI/AF activity in pFF in detail according to the follicular development. Its increase parallel to that of steroid concentration toward follicular maturation and the subsequent rapid decrease just before ovulation at high concentrations of steroids suggest that $\mathrm{GnSI} / \mathrm{AF}$ activity plays a role in the ovulatory process as an ovarian regulator for the timely occurrence of the LH surge.

The authors express their appreciation to S. Raiti (NIDDK) for the kind gift of RIA materials for rat FSH and LH. They also thank Y. Mori for expert technical assistance.

\section{References}

Anderson LD and Hoover DJ (1982) Hormonal control of inhibin secretion. In Intraovarian Control Mechanisms, pp 53-78 Ed. CP Channing and SI Segal. Plenum Press, New York

Busbridge NJ, Chamberlain GVP, Griffiths A and Whitehead SA (1990) Nonsteroidal follicular factors attenuate the self-priming action of gonadotropinreleasing hormone on the pituitary gonadotroph Neuroendocrinology 51 493-499

Culler MD (1992) In vivo evidence that inhibin is a gonadotropin surge inhibiting/attenuating factor Endocrinology 131 1556-1558

Danforth DG, Sinosich MJ, Anderson TL, Cheng CY, Bardin CW and Hodgen GD (1987) Identification of gonadotropin surge-inhibiting factor (GnSIF) in follicular fluid and its differentiation from inhibin Biology of Reproduction 37 1075-1082

de Koning J, Tijssen AMI and van Rees GP (1987) The involvement of ovarian factors in maintaining the pituitary glands of female rats in a state of low responsiveness to LHRH Journal of Endocrinology 112 265-273

de Koning J, Tijssen AMI and van Rees GP (1989) The self-priming action of LHRH increases the low pituitary LH and FSH response caused by ovarian factors: observation in vitro Journal of Endocrinology 120 439-447

Ferraretti AP, Garcia JE, Acosta AA and Jones G (1983) Serum luteinizing hormone during ovulation induction with human menopausal gonadotrophin for in vitro fertilization in normally menstruating women Fertility and Sterility $\mathbf{4 0} 742-747$

Fowler PA, Messinis IE and Templeton AA (1990a) Inhibition of LHRH-induced $\mathrm{LH}$ and FSH release by gonadotrophin surge-attenuating factor (GnSAF) from human follicular fluid Joumal of Reproduction and Fertility 90 587-594

Fowler PA, Messinis IE and Templeton AA (1990b) Gonadotrophin surgeattenuating factor (GnSAF) is produced preferentially by small follicles in superovulated women Journal of Reproduction and Fertility Abstract Series 5 Abstract 6

Fukuda M, Miyamoto K, Hasegawa Y, Ibuki Y and Igarashi M (1986) Action mechanism of inhibin in vitro - cycloheximide mimics inhibin actions on pituitary cells Molecular and Cellular Endocrinology $5141-50$

Guthrie HD, Rohan RM, Rexroad CE Jr and Cooper BS (1992) Changes in concentrations of follicular inhibin $\alpha$ and $\beta_{\mathrm{A}}$ subunit messenger ribonucleic Downloaded from Bioscientifica.com at 04/26/2023 11:19:45AM 
acid and inhibin immunoreactivity during preovulatory maturation in the pig Biology of Reproduction 47 1018-1025

Knight PG, Lacey M, Peter JLT and Whitehead SA (1990) Demonstration of a non-steroidal factor in human follicular fluid that attenuates the self-priming action of gonadotrophin-releasing hormone on pituitary gonadotropes Biology of Reproduction 42 613-618

Knobil E and Hotchkiss J (1988) The menstrual cycle and its neuroendocrine control. In The Physiology of Reproduction, Vol. 2 pp 1971-1994 Eds. E Knobil and I Neil. Raven Press, New York

Koppenaal DW, Tijssen AMI, van Dieten JAMJ and de Koning J (1991) The self-priming action of LHRH is under negative FSH control through a factor released by the ovary: observations in female rats in vivo Journal of Endocrinology 129 205-211

Koppenaal DW, Tijssen AMI and de Koning J (1992) The effect of gonadotrophin surge-inhibiting factor on the self-priming action of gonadotrophinreleasing hormone in female rats in vitro Journal of Endocrinology 134 427-436

Lagace L, Labrie F, Lorenzen J, Schwartz NB and Channing CP (1979) Selective inhibitory effect of porcine follicular fluid on follicle-stimulating hormone secretion in anterior pituitary cells in culture Clinical Endocrinology 10 401-405

Littman BA and Hodgen GD (1984) Human menopausal gonadotropin stimulation in monkeys: blockade of the luteinizing hormone surge by a highly transient ovarian factor Fertility and Sterility 41 440-447

Messinis IE and Templeton AA (1989) Pituitary response to exogenous LHRH in superovulated women Journal of Reproduction and Fertility 87 633-639

Messinis IE and Templeton AA (1991) Evidence that gonadotrophin surgeattenuating factor exists in man Journal of Reproduction and Fertility 92 217-223
Moore RM (1978) Macroscopic identification and steroidogenic function of atretic follicles in sheep Journal of Endocrinology 61 455-463

River C, Meunier H, Roberts V and Vale W (1990) Inhibin: role and secretion in the rat Recent Progress in Hormone Research 46 231-259

Schally AV, Redding TW and Arimura A (1973) Effect of sex steroids on pituitary responses to LH- and FSH-releasing hormone in vitro Endocrinology $93893-902$

Schenken RS and Hodgen GD (1983) Follicle-stimulating hormone induced ovarian hyperstimulation in monkeys: blockade of the luteinizing hormone surge Journal of Clinical Endocrinology and Metabolism 57 50-55

Schenken RS, Anderson WH and Hodgen GD (1984) Follicle-stimulating hormone increases ovarian vein nonsteroidal factors with gonadotropininhibiting activity Fertility and Sterility $\mathbf{4 2}$ 785-790

Sopelak VM and Hodgen GD (1984) Blockade of the estrogen-induced luteinizing hormone surge in monkeys: a nonsteroidal, antigenic factor in porcine follicular fluid Fertility and Sterility 41 108-113

Tang LKL and Spies HG (1975) Effects of gonadal steroids on the basal and LRF-induced gonadotropin secretion by cultures of rat pituitary Endocrinology 96 349-356

Tsonis CG, Quigg H, Lee VWK, Leversha L, Trounson AO and Findlay JK (1983) Inhibin in individual ovine follicles in relation to diameter and atresia Journal of Reproduction and Fertility 67 83-90

Vale W, Grant G, Amoss M, Blackwell R and Guillimin R (1972) Culture of enzymatically dispersed anterior pituitary cells: functional validation of a method Endocrinology 91 562-571

Whitehead SA (1990) A gonadotrophin surge attenuating factor? Journal of Endocrinology 126 1-4 